\title{
Regaining a Bright Future: Psychological Dynamics in Female Adolescent Victims of Sexual Harassment
}

\author{
Ajeng Nova Dumpratiwi ${ }^{1}$, Suci Murti Karini ${ }^{2}$, Aditya Nanda Priyatama ${ }^{3}$ \\ ${ }^{1}$ Faculty of Psychology, Universitas Muhammadiyah Surakarta \\ 1,2,3 Department of Psychology, Faculty of Medicine, Universitas Sebelas Maret \\ Submitted 22 April $2020 \quad$ Accepted 26 October $2020 \quad$ Published 27 October 2020
}

\begin{abstract}
Rampant sexual harassments affect the victims and need to be followed up. Victims who are majority women are likely to feel aggrieved by pregnancy, receive negative stigma from society, drop out of school, and feel unable to achieve well-being in the future. This phenomenon is the basis for research conducted with the aim of knowing the psychological dynamics and aspects that affect the psychological conditions in female adolescent victims of sexual harassment. The phenomenological approach and interview method were used in this research. Three teenage girls aged 13-18 years became informants in this study. The results showed that the psychological condition of victims of sexual harassment was influenced by who the perpetrator is or the close relationship between the victim and the perpetrator. It was also influenced by support from the social environment, especially family as the closest environment. The psychological dynamics of victims of sexual harassment are influenced by four things: 1) the attitude of the environment; 2) self-understanding ability; 3) motivation to achieve selfactualization; and 4) the attitude of comparing oneself with others who are not in a better condition. From the results of this study, it was concluded that the supporting external or environmental factors and internal process in victims of sexual harassment combined really encourage the process recovery to achieve a better future.
\end{abstract}

Keywords: adolescent; psychological dynamic; sexual harassment

Sexual harassment is one of the most common criminal offenses that have various impacts, especially on the victims. Minors or teenage victims have an increased risk of experiencing problems after experiencing sexual harassment. Adolescence, which is a period of selfdiscovery as well as stress and storm, is vulnerable when encountering life problems (Lerner \& Steinberg, 2014). Adolescence is a period to build a positive self-image or self-identity as the basis for personality or behavior to adapt and under-

Address for correspondence:

ajeng.dumpratiwi@ums.ac.id go each subsequent phase of life. Unfortunately, female adolescent who have experienced sexual harassment have various problems in their life i.e., unstable psychological dynamic.

Study by Augestad (2017) explained that negative experience can affect individual's self-esteem and self-concept. In addition, study conducted by Cucu-ciuhan \& Dumitru (2017) confirmed that sexual harassment can influence individual selfacceptance. Sexual harassment can affect emotions, cognition, social relationships, behavior functions, and behavioral problems of individual who experience it. The psychological dynamics discussed in 
this study are attitudes and assumptions that affect the respondents' acceptance of previous sexual harassment experiences as something that must be faced then move up to achieve their life goals. Szentagotai and David (2013) said that psychological dynamics in responding to one's state of self need to be developed because it can affect their well-being.

Therefore, this study aimed to determine the psychological dynamic as well as factors that affect psychological condition of female adolescents who were victims of sexual harassment. This study is important for determining the appropriate approach to help victims of sexual harassment achieve well-being in life despite their adversity.

\section{Method}

This qualitative study used phenomenology approach to understand individual perspective and philosophy derived from their experiences (existing phenomenon, reduction of phenomenon, variety of imaginations, and synthesis of meaning and essence of their experiences) (Worthington, 2013). Observation and semi-structured interviews were used as data collection methods. Self-acceptance construct consisting of self-evaluation and self-esteem aspects were used to compose the interview guideline (Bernard, 2013). Those aspects are broken down into self-disclosure, psychological health, and the ability to accept others (Popov, 2016). During the data collection process, this study focused on raw data in order to explore data without being framed by a theoretical framework. After that, the data were grouped into categories for analysis according to Creswell (2013).

This study used a purposive sampling technique to select subjects in accordance with research criteria and objective (Creswell, 2013). One of the main sampling criteria for this study is female adolescents age 13-18 who according to Hurlock (2014) are in the search for identity as a compass for subsequent phases of life as well as having more concern in their self-image. Researchers' first meeting with respondents was to ask their willingness to participate in the study by filling out the informed consent. Three respondents were L, F, and B from Surakarta City who experienced pregnancy after becoming victims of sexual harassment. They had middle to lower economic backgrounds and received diverse parenting styles.

\section{Results}

\section{Research subject descriptions}

There were three research respondents with various backgrounds e.g., age, sexual harasser, and life before and after sexual harassment (see table 1).

\section{Research data descriptions}

In Surakarta, there were about 30-50 sexual harassment cases among adolescents from 2013 to 2015. The data was collected from Surakarta City Police, K foundation, and Perlindungan Perempuan dan Anak (Women and Child Protection PPA) Surakarta. Victims of sexual harassment were mostly female aged 5 to 18 years. Sexual harassment types recorded at $\mathrm{K}$ Foundation (the foundation that assists 
victims of sexual harassment in Surakarta) were mostly rape and sodomy.

\section{Respondent $L$}

Respondent L was a junior high school student aged 17 who experienced sexual harassment from a stranger. L, who rode pedicab on her way home, was raped by the driver. The incident resulted in her pregnancy. As a student, she was not ready to have children of her own. L was very ashamed of her circumstance, moreover her family refused to acknowledge her sexual harassment. The school negatively judged as $\mathrm{L}$ a naughty student who had pregnancy out-of-wedlock. Her schoolmates also gave her similar judgement. She experienced rejection and did not receive support when undergoing trial process nor coping with her post-sexual harassment circumstances.

L, who was not ready and lack of adequate support, opted to drop out of school because she felt that she had lost her future. She felt serene and protected after the perpetrator was sentenced and could focus on herself. L sought pleasure and mingled with random people who made her feel accepted. She carelessly looked for a boyfriend and behaved recklessly because her partner will not question her label as a victim of sexual harassment who have a child out of wedlock.

Due to limited support and acceptance from her surrounding, L vented her disappointment by carelessly and freely socializing outside of her home to compensate for her sexual harassment experience. She also expressed loneliness and cluelessness to seek help when she did not receive support from her environment, causing her to look for happiness outside of it. Additionally, she felt unmotivated to make her family happy after losing their support. The lack of acceptance by her environment also caused her loss of motivation to pursue her dream.

\section{Respondent F}

Respondent $\mathrm{F}$ was a senior high school student aged 18 who experienced sexual harassment from a close relative, namely her neighbor. $\mathrm{F}$ was afraid to report the incident because she felt threatened by the perpetrator who lived next door, she was afraid that her family would not believe her because of her family closeness with the perpetrator. F got pregnant unpreparedly because of the incident. Eventually, her family found out about her circumstance and reported the perpetrator after noticing her pregnancy signs and she opened up the sexual harassment incident to her family.

Her family accepted her circumstance and provided support by assisting and accompanying throughout her pregnancy even though she had miscarriage due to weak physical condition and fatigue during the trial process, persuading her to attend therapy or get professional help and joining a foundation that shelters victims of sexual harassment, as well as supporting her education by allowing her to take school leave for recovery process. According to $\mathrm{F}$, family or environmental support made her feel not alone, helped her understand and bounced back from the circumstance. $F$ also received guidance from the foundation sheltering victims of sexual harassment to find meaning of the incident. Environmental acceptance, guidance, and support helped her to find meaning following the incident. 
F realized that sexual harassment is not the end of her world, but only a little part of it. She believed she still have a chance to create a better future dan prove that victims of sexual harassment can succeed like other adolescents.

$$
\text { Initially, F rejected her }
$$
circumstance of sexual harassment, yet her family helped her to accept it while provided space for her to share her thoughts and seek help or protection. F was angry and disappointed because she trusts her neighbor too much which led to the sexual harassment. She felt relieved after comparing her circumstances with other victims of sexual harassment from the foundation who had worse experiences e.g., kicked out of their families because of shame, expelled from school, and raising children without family support. Positive meaning of events also emerged from this comparison process so that she could accept her circumstance.

\section{Respondent B}

Respondent $\mathrm{B}$ was the youngest respondent in this study, a junior high school student aged 13. She was sexually harassed by her private driver who used to escort her to school. She experienced pregnancy at the age of 13 and gave birth to a baby boy. The baby was raised by her relatives who were childless because her parents thought that she was too young and not ready for motherhood. Additionally, her parents moved B out of her school to prevent her from being bullied; moreover she was left behind in her study due to attending trials. B was traumatized, regretted knowing the perpetrator, felt threatened, had trust issues, and scared of new people or the perpetrator, even though he already got sentenced. Previously, B said that she was afraid to report the incident because her parents trusted their driver and he could meet her anytime due to his nature of work.

Her parents realized that she needed help so they persuaded her to join a foundation that shelters victims of sexual harassment in order to get professional help. Her parents actively participated in parents' sessions for assisting child victims of sexual harassment. Her parents' cooperation significantly helped her to not feel alone and felt treated according to her circumstance. Those conditions motivated B to keep pursuing her dreams. Her parents, who actively accompanied and talked to B in accordance with professional guidance, helped $B$ to accept and find positive meaning to her circumstance. B believed she can pursue her dreams because what happened in the past stayed in the past and there was still a future for her. Her parents' presence encouraged $\mathrm{B}$ to be invigorated and careful in living her life after the incident.

Interview results showed that sexual harassers in study were a pedicab driver, a private driver, and a neighbor. Parents lacked of awareness due to trust and judged that it was impossible for a known person to harm their child was a great opportunity for the perpetrator to commit sexual harassment. Moreover, respondents were afraid to report it because they knew the perpetrators. They were traumatized and frightened after being sexually harassed by their known or close related person because they were threatened, frequently met, had close relations, and 
regretted trusting and knowing the perpetrators.

Respondents, who were still teenagers, were closely linked to education
The influence of environmental support was seen from the three respondents. Respondent who did not receive family or environmental support

Table 1.

Details of Respondents

\begin{tabular}{|c|c|c|c|c|c|c|c|}
\hline No & $\begin{array}{l}\text { Respondent } \\
\text { Initials }\end{array}$ & $\begin{array}{l}\text { Age } \\
\text { (Year) }\end{array}$ & \multicolumn{2}{|c|}{ Sexual abusers } & $\begin{array}{c}\text { Education } \\
\text { before sexual } \\
\text { harassment }\end{array}$ & $\begin{array}{c}\text { Education } \\
\text { after sexual } \\
\text { harassment }\end{array}$ & $\begin{array}{l}\text { Condition } \\
\text { after sexual } \\
\text { harassment }\end{array}$ \\
\hline & & & $\begin{array}{c}\text { Known } \\
\text { or close } \\
\text { related } \\
\text { person } \\
\end{array}$ & Stranger & & & \\
\hline 1. & $\mathrm{~L}$ & 17 & & $x$ & $\begin{array}{l}\text { Junior high } \\
\text { school }\end{array}$ & Dropout & Pregnant \\
\hline 2. & $\mathrm{~F}$ & 18 & $x$ & & $\begin{array}{l}\text { Senior high } \\
\text { school }\end{array}$ & $\begin{array}{l}\text { Continued } \\
\text { education }\end{array}$ & $\begin{array}{l}\text { Pregnant } \\
\text { (Miscarriage) }\end{array}$ \\
\hline 3. & B & 13 & $\mathrm{X}$ & & $\begin{array}{l}\text { Junior high } \\
\text { school }\end{array}$ & $\begin{array}{l}\text { Continued } \\
\text { education, } \\
\text { changed } \\
\text { school }\end{array}$ & Pregnant \\
\hline
\end{tabular}

or school system. After experiencing sexual harassment, respondents were pressured to complete their education. Their unwanted pregnancies along with undergoing long trial processes made them find it difficult to stay focused at school. Respondents were isolated and looked down upon by their friends and teachers at school. Those situations also made them feel embarrassed to attend school. Respondents yearned for similar experience as their peers who can freely do activities without trauma or burdens as victims of sexual harassment. Victims of sexual harassment with those situations most likely do not accept their pregnancies, thus they would try to abort it by doing dangerous actions. If the pregnancy continues until birth, victim of sexual harassment would hate, ignore, or disown the baby because it is unwanted and considered as a burden. had lost her life purpose because she was in a disadvantaged situation, alone, and without shelter and help. Thus, it made her vent the disappointment and hopelessness to pursue her dreams by seeking pleasure from the outside world. She chose to spend her time by having fun, hanging out with promiscuous friends because they accepted the respondent's circumstance, and dating any man for fun. She would find an environment where she can be accepted and provide pleasure as a compensation for her sexual harassment experience. Due to no support from her family, she had no motivation to make them proud and gave up on her future. On the other side, respondents who were supported by their family or environment could passionately pursue their dream to make their family happy. These supports helped them to seek help, feel not alone, and think positively 
that they still have a chance for their better future. The role of family and environment were very helpful in guiding and steering respondents to be more adaptive with their circumstances and to accept themselves as victims of sexual harassment.

The three respondents had their turning point when they were able to find meaning following sexual harassment as a past incident, had certain lessons, and a small part of their life. Therefore, they still had a chance to pursue a better future. Such assumption emerged after respondents received environmental support i.e., parental assistance, teachers' help at school, legal assistance from related agencies or foundations. Support was an important attribute for victims of sexual harassment to be able to cope in order to be accepted, mindfulness of the incident, and feel worthy so they can continue pursuing their dreams. Respondents perceived the incidents as valuable lessons for provision of their future life. In addition, respondents thought they still had a chance for a better future when they rose up and took lessons from their experiences. If they never tried to cope, they would not have a chance to change their future and make their supportive family or environment proud. On the other side, respondent who were unsupported by their family or environment would find meaning to the incident in despair. The young respondents' mental unreadiness to suffer the repercussion of sexual harassment such as pregnancies, would affect their psychological condition. In fact, their experience as victims of sexual harassment made them have a desire to become prostitutes because they felt they have no self-regard and no point to pursue their future. Those circumstances made respondents feel useless, meaningless, have no positive side in life, burdens for their family, do not have the same standing with others to be respected, and lose their potential and future.

\section{Discussion}

Victims of sexual harassment experience traumatic events that affecting their lives. They experience rape, unwanted pregnancies, mistreated by their environments, and have difficulties to pursue their dreams. According to analysis results shown in figure 1 (see page 131) there are four factors that affect respondents' circumstance as victims of sexual harassment.

From figure 1, it can be seen that psychological dynamic of victims of sexual harassment is affected by four important factors. First, social environmental attitudes toward victims of sexual harassment. Second, victims' ability to find meaning following sexual harassment. Third, motivation to achieve self-actualization. Fourth, self-comparison with other victims who are less fortunate.

The first discussion is about social environmental attitudes that affected by negative stigma on victims of sexual harassment. Previous study explained that negative attitudes and stigma from the social environment lead to rejection of pregnancy, low self-esteem, and low selfesteem in adolescents. Some families also consider sexual harassment as a disgrace (Azizah \& Hastuti, 2019). Other study also explained that adolescents with family 
conflict find it difficult to cope with traumatic experiences (Ruswahyuningsih \& Afiatin, 2015). Negative stigma often times inflicts in environment unable to provide social support for victims of sexual harassment. Adolescents who experience pregnancy are going through rejection and acceptance processes. Adolescents who reject their pregnancy would have low selfesteem because they also experience rejection and bullying, oftentimes verbal bullying, from the environment. Parents who aggressively reject unwanted pregnancy have a significant effect toward adolescent's mental health (Azizah \& Hastuti, 2019). Environment with negative stigma can causes mistreatment and psychosocial problems for victims of sexual harassment who supposedly need to be handled with warm and familial attitudes (Kakkad, Trivedi, Trivedi, \& Raichandani, 2014). Social support is beneficial to reduce the level of psychological disorders e.g., depression, anxiety, and stress (Bukhari \& Afzal, 2019). Emotional social support can contribute to reducing susceptibility to psychological distress. Besides that, it is useful for individual ability to adapt with the environment (Sterle, Vervoort, \& Verhofstadt, 2018). Environmental attitudes in supporting victims of sexual harassment can be in the form of providing education, helping to seek assistance to the authorities, supporting victims to build healthy relationships, helping to monitor victims with their surrounding, and accompanying teenagers or victims when leaving house at late night (Gwirayi, 2013). Aside that, supporting independent activities, peer friendships, and social interaction also provides opportunity for successful development and positive self-evaluation (Augestad, 2017) as well as generates selfacceptance in victims of sexual harassment (Walęcka-Matyja, 2014).

The second factor that affecting the life of victims of sexual harassment is the ability to find meaning following sexual harassment. To find meaning or mindfulness is also an important factor in achieving self-acceptance. Cognitive function to find meaning can greatly affect behavior and attitudes that will emerge (Carson, Gilmore, Perry, \& Gronhaug, 2011). Personal and spiritual dimensions in interpreting situations will help victims of sexual harassment recovery process related to physical and social impacts they experience (Robinson, Mill, \& Strickland, 2009). Meanwhile, adolescents who do not have the ability to find meaning can affect their self-esteem dynamic and social skills (Srivastava \& Joshi, 2014). There are victims who find meaning of sexual harassment as a fate that must be accepted, as well as victims who find it a meaning as adverse events in their life. The ability to see oneself in women is sometimes biased due to the cultural influence that surrounds them, so it is not uncommon for women to develop negative thoughts of themself. Those affect self-acceptance in women (Hernandez, 2014). Negative meaning of life events will affect self-esteem and self-concept of adolescents (Palacios, Echaniz, Fernández, Camino, \& Barrón, 2015). Emotional and self-management to find meaning in life will affect self-acceptance, self-esteem, and reduce the level of depression in adolescents (Cucu-ciuhan \& Dumitru, 2017). Self-esteem and self-acceptance are correlated with individual health and 
mindset. Anxiety symptoms affect mood which will be related to self-esteem and self-acceptance (Birgisdóttir, 2015). The ability to find meaning in life has a positive affect in achieving self-acceptance. It is related to positive cognitive ability that affects behavior. Individual behavior toward life events is more adaptive and able to respond positively with full acceptance (Magnano, Paolillo, \& Giacominelli, 2015).

The third factor is motivation to achieve self-actualization. Self-actualization is the highest hierarchy of needs in accordance with Maslow's theory (Taormina \& Gao, 2013). Need for selfactualization encourages individuals to achieve their goals. Self-actualization is beneficial to foster self-perception if individuals have achieved their goals (Pratika \& Puspitadewi, 2014). Victims of sexual harassment will gain positive experience by achieving self-actualization phase then it stimulates positive perception of their own selves. In addition, selfactualization increases confidence and motivation because they have achieved their goals (Patioran, 2013). Victims of sexual harassment who have selfconfidence will be brave to socialize and mingle in their community and have more motivation to continue pursuing their future (Syauta \& Yuniasanti, 2015). Previously, it is stated that psychological dynamic is also affected by meaning in life. Study by Septiani (2018) showed the ability to self-actualize helps individuals to find positive meaning in life. Therefore, selfactualization helps victims of sexual harassment to rise and to pursue a better future.
Lastly, the comparative attitude or comparison with others. Comparison affects individual attitudes (Dinengsih \& Agustina, 2018). Data analysis showed other factor that affects the emergence of positive attitudes in victims of sexual harassment is self-comparison with other victims whose condition are less fortunate. The attitude of comparing with someone who is less fortunate will generate gratitude, respect, cherish, and love oneself (Putra, 2018). Positive attitudes toward oneself will play an important role in the process of rising from adversity, and also raise self-confidence in victims of sexual harassment (Denich \& Ifdil, 2016). Victims of sexual harassment will be able to accept theirselves after seeing others who are not better off than them (Handayani, Ratnawati, Helmi, \& Mada, 2015). Selfcomparison helps victims of sexual harassment to be more accepting of themselves under any circumstances and to have motivation to prepare for a better future.

\section{Conclusion}

It can be concluded from data analysis that the identity of sexual harassment perpretator affects victim's degree of fear and trauma. Besides that, social support significantly helps victims to cope with their post-sexual harassment life. Victims' psychological dynamic process starts from the denial phase to acceptance and cope to pursue their future is influenced by environmental attitudes, perceived selfmeaning, self-actualization, and the attitude of comparing with others who are in similar predicaments. Attitudes from within as 
well as environment are important in arousing the spirit of victims of sexual harassment to keep pursuing for their brighter future.

\section{Implication}

The results of this study can be referred to compose a more appropriate approach in handling victims of sexual harassment, especially to foster their mental health. Furthermore, it can also be used as a consideration in nurturing positive support to cope from traumatic experiences. Subsequent study can explore various characteristic backgrounds of victims of sexual harassment to produce new findings in order to design better intervention.

Acknowledgment. This study was supported by K Foundation, Surakarta who helped researchers by providing assistance and input throughout data collection with victims of sexual harassment. Aside that, Perlindungan Perempuan Anak Surakarta, an agency under Surakarta Regional Government and Surakarta Police also helped researchers in collecting information about sexual harassment cases in Surakarta. This study would not have happened without support from Universitas Muhammadiyah Surakarta as researchers' affiliate institution who helped with data collection permission.

Competing interest. There is no competing interest with regards to this research.

\section{References}

Augestad, L. B. (2017). Self-concept and self-esteem among children and young adults with visual impairment: A systematic review. Cogent Psychology, 4(1), 1-12. doi: https://doi.org/10.1080/23311908.2017.1 $\underline{319652}$

Azizah, S. A. N., \& Hastuti, D. (2019). The influence of maternal acceptancerejection and adolescents self esteem to bullying behavior junior high school students. Journal of Family Science, 4(1), 12-25.

doi:

https://doi.org/10.29244/jfs.4.1.12-25

Bernard, M. E. (Ed.) (2013). The strength of self-acceptance: Theory, practice, and research. New York, NY: Springer.

Birgisdóttir, Í. H. (2015). The effect of sexual abuse on self-esteem among adolescent: The impact of gender, parental support and type of perpetrator (Unpublished bachelor's thesis). Department of Psychology, Reykjavík University, Reykjavík.

Bukhari, S. R., \& Afzal, F. (2019). Perceived social support predicts psychological problems among university students. The International Journal of Indian Psychology, 4(2), 18-27.

Carson, D., Gilmore, A., Perry, C. \& Gronhaug, K. (2001). Writing qualitative research reports. In Carson, D., Gilmore, A., Perry, C., \& Gronhaug, K. Qualitative marketing research (pp. 188-203). London: SAGE Publications, Inc.

Creswell, J. W. (2013). Qualitative inquiry and research design: Choosing among the five approaches (3rd ed.). London: SAGE Publications, Inc.

Cucu-ciuhan, G., \& Dumitru, I. E. (2017). Unconditional self-acceptance, 
functional and dysfunctional negative emotions, and self-esteem as predictors for depression in adolescents: A brief pilot study conducted in Romania. Journal of Experiential Psychotherapy, 20(4), 30-38.

Denich, A. U., \& Ifdil. (2016). Konsep kepercayaan diri remaja putri. Jurnal Educatio: Jurnal Pendidikan Indonesia, 2(2), 43-52.

Dinengsih, S., \& Agustina, M. (2018). Hubungan antara pola asuh orang tua dan pengetahuan ibu terhadap sibling rivalry pada anak usia 3-5 tahun di TK Aisyiah Bantul Yogyakarta tahun 2017. Jurnal Akademi Keperawatan Husada Karya Jaya, 4(1), 1-8.

Gwirayi, P. (2013). Fighting child sexual abuse: Perspectives of pupils from a developing country. SAGE Open, 3(1), 1-10.

doi:

https://doi.org/10.1177/21582440124726 $\underline{87}$

Handayani, M. M., Ratnawati, S., Helmi, A. F., \& Mada, U. G. (2015). Efektifitas Pelatihan Pengenalan Diri terhadap peningkatan penerimaan diri dan harga diri. Jurnal Psikologi, 25(2), 47-55.

Hernandez, P. A. (2014). The right reflection: Improving women's self- acceptance (Unpublished master's thesis). Master of Applied Positive Psychology, University of Pennsylvania, Philadelphia.

Hurlock, E. (2014). Perkembangan anak (6th edition). Jakarta: Penerbit Erlangga.

Kakkad, A., Trivedi, M., Trivedi, G., \& Raichandani, A. (2014). Study for adolescent problem and psychology. Journal of Evolution of Medical and Dental Sciences, 3(37), 9564-9574. doi: https://doi.org/10.14260/jemds/2014/32

$\underline{37}$

Lerner, R. M., \& Steinberg, L. (2014). Handbook of adolescent psychology (2nd edition). Hoboken, NJ: John Wiley \& Sons.

Magnano, P., Paolillo, A., \& Giacominelli, B. (2015). Dispositional optimism as a correlate of decision-making styles in adolescence. SAGE Open, 5(2), 1-12. doi:

https://doi.org/10.1177/21582440155920 $\underline{02}$

Palacios, E. G., Echaniz, I. E., Fernández, A. R., Camino, I., \& Barrón, O. De. (2015). Personal self-concept and satisfaction with life in adolescence, youth and adulthood. Psicothema, 27(1), 52-58. doi:

https://doi.org/10.7334/psicothema2014 $\underline{.105}$

Patioran, D. N. (2013) Hubungan antara kepercayaan diri dan aktualisasi diri pada karyawan PT. Duta Media Kaltim Press (Samarinda Pos). Motivasi, 1(1), 10-18.

Popov, S. (2016). Unconditional selfacceptance and mental.health in egoprovoking experimental context. Suvremena Psihologija, 19(1), 71-80. doi: https://doi.org/10.21465/2016-SP-191$\underline{06}$

Pratika, E., \& Puspitadewi, N. W. S. (2014). Aktualisasi diri dan persepsi terhadap pelaksanaan pelatihan pada karyawan. Jurnal Psikologi Teori Dan Terapan, 5(1), 7-14.

doi: https://doi.org/10.26740/jptt.v5n1.p7-14 Putra, J. S. (2018). Peran syukur sebagai moderator pengaruh perbandingan sosial terhadap self-esteem pada 
remaja pengguna media sosial. Psikohumaniora: Jurnal Penelitian Psikologi, 3(2), 197-210. doi: https://doi.org/10.21580/pjpp.v3i2.2650 Robinson, K., Mills, K. T., \& Strickland, A. L. (2009). Female childhood sexual abuse survivors: An existential exploration and implications for therapists. Alabama Counseling Association Journal, 37(1), 11-23.

Ruswahyuningsih, M. C., \& Afiatin, T. (2015). Resiliensi pada remaja Jawa. Gadjah Mada Journal of Psychology (GamaJoP), 1(2), 96-105.

Septiani, N. H. (2018). Hubungan antara tingkat aktualisasi diri dengan kebermaknaan hidup pada pria homoseksual. Psympathic: Jurnal Ilmiah Psikologi, 4(1), 263-277. doi: https://doi.org/10.15575/psy.v4i1.2195

Srivastava, R., \& Joshi, S. (2014). Relationship between self-concept and self-esteem in adolescents. International Journal of Advanced Research, 2, 36-43.

Sterle, M. F., Vervoort, T., \& Verhofstadt, L. L. (2018). Social support, adjustment, and psychological distress of helpseeking expatriates. Psychologica Belgica, 58(1), 297-317. doi: https://doi.org/10.5334/pb.464

Syauta, B. A., \& Yuniasanti, R. (2015).
Hubungan antara kebutuhan aktualisasi diri dengan motivasi kerja pada wanita karier di PT Kusuma Sandang Mekarjaya. Insight: Jurnal Ilmiah Psikologi, 17(1), 49-55.

Szentagotai, A., \& David, D. (2013). SelfAcceptance and happiness. In $\mathrm{M}$. Bernard (Ed.), The Strength of SelfAcceptance (pp. 121-137). New York, NY: Springer.

Taormina, R. J., \& Gao, J. H. (2013). Maslow and the motivation hierarchy: Measuring satisfaction of the needs. American Journal of Psychology, 126(2), 155-177. doi: https://doi.org/10.5406/amerjpsyc.126.2 .0155

Walęcka-Matyja, K. (2014). Adolescent personalities and their self-acceptance within complete families, incomplete families and reconstructed families.. Polish Journal of Applied Psychology, 12(1), 59-74.

Worthington, M. (2013). Differences between phenomenological research and a basic qualitative research design. Retrieved from

http://a1149861.sites.myregisteredsite.c om/DifferencesBetweenPhenomenolog icalResearchAndBasicQualitativeResea rchDesign.pdf 
Victims of sexual harassment

Emotions, thoughts, and attitudes following sexual harassment:

1. Loneliness

2. Denial

3. Anger disappointment

4. Trust issues

5. Hopelessness and

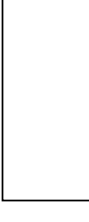

Feeling lost about future, ashamed, stress, trauma, rejection, negative labeling from environment

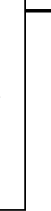

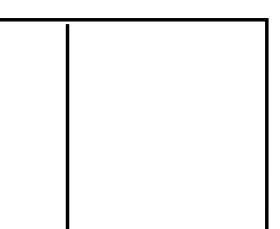

Anger and trauma. Respondent could focus on her life after trial finished.

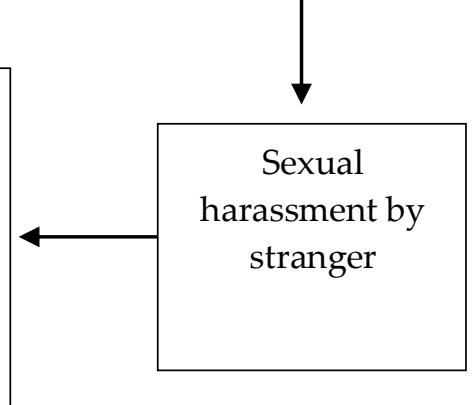

Trauma, regretted for knowing the perpetrators, threatened, trust issues, scared to meet the perpetrators or others after trials.
Sexual harassment by known or close relative
Comparison with other victims in foundation who are in less fortunate circumstances

Motivated to prove oneself and believe that sexual harassment is not the end of life
Supported by environment
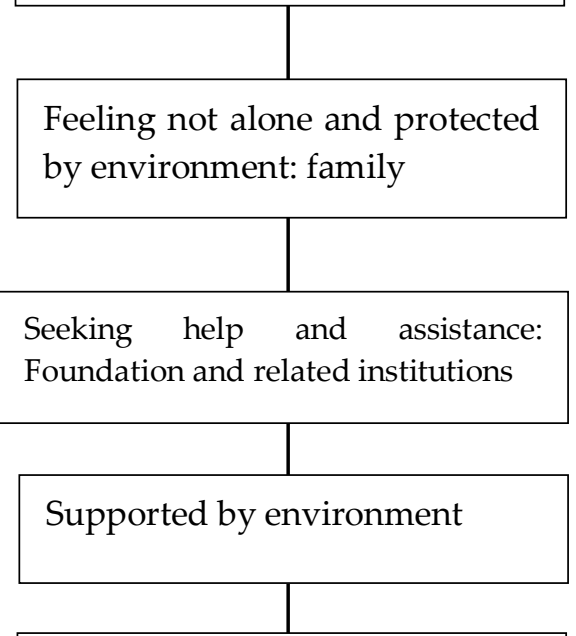

Self-acceptance and realizing to still have is still positive side

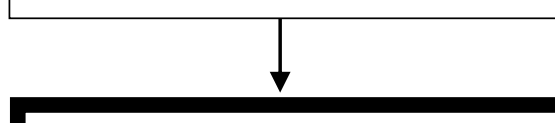

Passionate to pursue dreams and to make family happy
Unsupported by environment due to negative stigma

Feeling alone and helpless

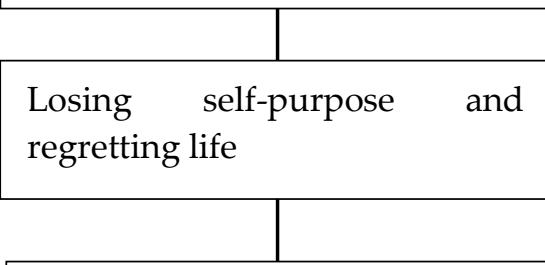

No self-acceptance

Regarding oneself as having no positive aspect

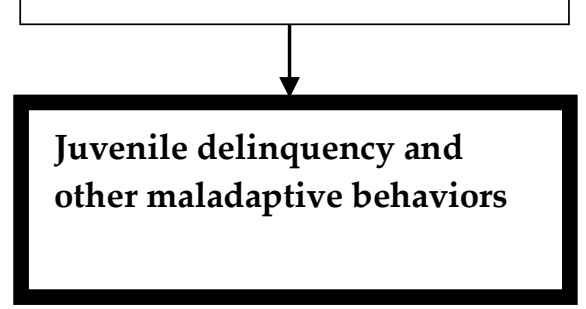

Figure 1. Illustration of psychological dynamics of victims of sexual harassment in 